\title{
The Existence of the Betel Leaf (Piper betle L.) is in the Tasawuf Prespective
}

\author{
R Rahmatika $^{1}$, D Hartono ${ }^{2}$, Hartoyo $^{3}$ \\ ${ }^{1}$ Islamic Building School of Jagad Alimussirry Surabaya, Indonesia \\ ${ }^{2} \mathrm{Al}-$ Khoziny Islamic Institute Sidoarjo, Indonesia \\ ${ }^{3}$ Department of Biology Education, Universitas Negeri Malang \\ Email: resty_rahmatika@yahoo.com
}

\begin{abstract}
Plants are one of the richest natural resources in Indonesia and contain active chemicals. These plants have the potential to become raw materials for traditional medicine. One of them is betel plant. The use of Betel leaves, especially in Java, is generally accompanied by special conditions or criteria, namely: betel leaf which 'meets ros-e'. 'Ros' comes from the Javanese language which means vein, in this case it is a vein of leaves. 'Temu' comes from the Javanese language which means to meet, meet. Betel rose meeting is betel which leaves veins (lateral nerves) meet the position of the segment; so that the shape is symmetrical. Meanwhile, phytochemical laboratory test results for total flavonoid content of betel leaves and non-temurose leaves were 53,522 and 43,041 ppm. These values include high levels (> $50 \mathrm{ppm}$ ) and moderate levels (between>10-50 ppm). The higher the level of flavonoids, the more likely the antioxidant potential will be. In the implementation of riyadhoh, making betel leaves meet rose as a medium as a form of philosophy that is betel or tell me means ngangsu kaweruh (studying), whereas meet rose can be interpreted as meeting taste.
\end{abstract}

Keywords: betel leaves; temurose; sufism; tasawuf;

\section{INTRODUCTION}

Plants are one of the richest natural resources in Indonesia and contain active chemicals. These plants have the potential to become raw materials for traditional medicine. One of them is betel plant. Betel leaf is one form of concoction traditional right in this treatment because it has It is known that some ingredients are possessed by betel plants . Two different betel varieties are green betel and red betel vine has a different chemical content, and is very capable as an antifungal or as an antibacterial. In this study researchers wanted to use extract green betel leaf ( Piper betle L.) as a literature study.

Betel is an Indonesian native plant that grows creatively, which in Indonesian society is synonymous with culture. The use of Betel leaves, especially in Java, is generally accompanied by special conditions or criteria, namely: betel leaf which 'meets ros-e'. 'Ros' comes from the Javanese language which means vein, in this case it is a vein of leaves. The phenomenon of the use of betel accompanied by conditions uses bone leaves the leaves are symmetrical or 'meet rose' . The Javanese tradition which is juxtaposed with Sufism, the concept of Sufism views that heart is the subject of discussion in which the movement of birth is determined by inner motion. If someone's heart is clean it will give birth to noble behavior. For the heart, which is filled with the glory of God, the world is not a special item. Thus, humans will find a true sense of God. For that reason, in this study, researchers wanted to raise the title, "The Existence of Betel Leaves in the View of Sufism".

\section{METHOD}

This type of research is library research , namely a series of studies relating to library data collection methods, or research whose research objects are explored through a variety of library information (books, encyclopedias, scientific journals, newspapers, magazines, 
and documents) The focus of library research is to find various theories, laws, arguments, principles, or ideas that are used to analyze and solve the research questions formulated. The nature of this research is descriptive analysis, namely the regular breakdown of data that has been obtained, then given an understanding and explanation to be well understood by the reader.

The data collection method used in this study is the documentation method. Documentation method is a method of collecting data by looking for or digging data from the literature related to what is meant in the formulation of the problem (Arikunto, 2013). Data analysis used in this study is the fenomenology and critical analysis on kualitatif research.

\section{RESULT AND DISCUSSION}

\section{A. Betel Leaf "Temu Rose"}

Betel leaves 'temurose' is betel leaf veins (lateral nerves) that meet the position of the segment, so that the shape is symmetrical (Ekosari \& Sugiarto, 2013). The use of Betel leaves, especially in Java, is generally accompanied by special conditions or criteria, namely: betel leaf which 'meets ros-e'. 'Ros' comes from the Javanese language which means vein, in this case it is a vein of leaves. 'Temu' comes from the Javanese language which means to meet, meet. Betel rose meeting is betel which leaves veins (lateral nerves) meet the position of the segment; so that the shape is symmetrical (Ekosari \& Sugiarto, 2013).

The electrical conductivity of temurose leaves is greater than that of non-temurose, although the value of fresh weight and dry weight is smaller. If you look only at the weight or weight, then the betel leaf which has a large loss, but if you see it together with the value of electrical conductivity, where the temperature is greater, then it can indicate that the electrolyte solute is sufficient high in leaves that are temurose (Ekosari \& Sugiarto, 2013).

Meanwhile, phytochemical laboratory test results for total flavonoid content of betel leaves and non-temurose leaves were 53,522 and 43,041 ppm. These values include high levels (> $50 \mathrm{ppm})$ and moderate levels (between> $10-50 \mathrm{ppm}$ ). The higher the level of flavonoids, the more likely the antioxidant potential will be (Ekosari \& Sugiarto, 2013).

\section{B. The Role of Existence of Betel Leaves in the View of Sufism}

Sufism is a branch of science that emphasizes the spiritual dimension rather than material, hereafter rather than mortal, and mental rather than born (Armando, 2005). Sufism is divided into three parts, namely morality Sufism, Amali Sufism and philosophical Sufism. These three forms of Sufism cannot be separated because the practices of the three Sufism are interrelated (Amin, 2002). As for what is meant by Sufism amali is a teaching in Sufism which emphasizes more spiritual practices than theory. Which in tasawuf amali has the same goal which is to draw closer to Allah SWT by abolishing all traits that are despicable and fully adhering to Allah SWT with a variety of amaliah or riyadhoh carried out, such as multiplying wirid and other amaliyah. Amali Sufism is more synonymous with Tariqah, which is a form of practice that has been done (Anwar, 2004).

In the implementation of riyadhoh making betel leaves meet rose as a medium as a form of philosophy that is betel "suruh" means ngangsu kawruh (studying), whereas meet rose can be interpreted as meeting taste (Kompasiana, 2016). In another reference, the betel leaf which "meet Rose" or met its leaf segments depicts true brotherhood will be established if it is based on meeting the tasteor heart (Fauzan, 2012). As the concept of Sufism is that the heart is the subject of discussion in which motion is determined by the inner motion that unites itself with God (Anwar, 2004).

\section{Reasons for the Existence of Betel Leaves Have an Important Role in the Perspective of Sufism}

\section{Theocentric Reason}

Sufism is a branch of Islamic science that emphasizes the spiritual aspects of Islam (Kartanegara, 2006). Sources of Sufism teachings originated from the teachings of Islam itself, namely the Qur'an and Hadith (Haidir, 2019). In the Qur'an many mention about plants for human use. Plants are an important component in human life, especially as a food source and as medicine. Plants empirically have antimicrobial activity. As the 
word of Allah SWT in the Qur'an, the letter Thaha verse 53 which means: "For you the earth is a stretch and that has made for you on earth a walk, and lowered it from the sky of rain. Then the earth grows with rain water, various kinds of plants, "Allah SWT created various types of plants, from high plants to low levels and behind their creation there are many benefits that we can take from them, because there is nothing created by Allah that is something that is in vain, no matter how small his creation must have benefits for survival humans (Latifah, 2015). For example, betel leaf (Piper betle L.) which is one type of medicinal plant that is often used since long ago to maintain health, prevention and treatment of various diseases. (Putri, N.R, \& Effa, 2015). In addition, spiritual science teaches that there is a healing tattoo that will be scratched into each betel leaf then prayed for and used as a healing medium (Hidayah, 2019).

\section{Psychological reasons}

From the psychological aspects of betel leaf has a main component is a green betel leaf essential oil (Patel \& Jasrai, 2013). Essential oils contain aromatherapy which is able to relieve stress and relax the body. In this finding, betel leaf is considered to be able to provide an aromatherapy effect which can be used as a therapy to encourage the spirit of spiritual activity. Ali, et.al., (2015) suggested that the use of essential oils is important for therapy, aromatic, perfume, and also used for spiritual. The benefits of aromatherapy products for human health include relaxation of the body, refreshing the mind, improving mood, and as a placebo in healing physiological effects (Ali , et . Al ., 2015) and as an antioxidant (Wei \& Shibamoto, 2010; Gavankar, et.al., 2013).

Green betel leaves also have benefits as antibacterial because in them there are phenol and their derivatives, especially tannins, flavonoids, and saponins which are known as antibacterial (Carolia \& Noventi, 2016; Ibrahim, 2013). In addition, Betel is also commonly used to treat body odor and mouth, thrush, nosebleeds, itching, sores, and treat vaginal discharge in women (Fauziah, 2007; Inayatullah, 2012; \& Muhlisah, 2007). If a person's body is healthy and clean it will affect one's soul or soul. So that angels will dwell in one's soul. If angels are present in someone's soul, the angel will come whispering the joy and calm in the person's heart (Asy-Syafrowi, 2013).

\section{Science Reasons}

Betel leaf ( Piper betle L.) in the world of pharmacology has a variety of chemical content that has many benefits. Flavonoids are one of the largest natural phenol groups. Plants containing flavonoids can be used as anticancer, antioxidant, anti-inflammatory, hypo-allergenic, and antihypertensive (Fauziah, 2010). The important role of flavonoids from vegetables and fresh fruit is to reduce the risk of heart disease and stroke (Safitri, 2004). Plants that contain flavonoids can also be used as anticancer, antioxidant, anti-inflammatory, hypo-allergenic, and antihypertensive (Aiello, 2012) and antibiotics (Putri, 2010).

Betel leaves 'temurose' is betel leaf veins (lateral nerves) that meet the position of the segment, so that the shape is symmetrical (Ekosari \& Sugiarto, 2013). The green betel leaves that meet rose have a flavonoid content of $53,522 \mathrm{ppm}$, while the betel leaves which do not meet rose found flavonoid content of 43,041 ppm (Ekosari \& Sugiarto, 2013). It can be concluded that the content of the flavonoid of betel leaf meet rose is greater than that of betel leaf which does not meet rose. Thus, betel leaves meet rose has greater antioxidants than betel leaves do not meet rose.

\section{CONCLUSION}

Based on the formulation of the problem proposed and discussed above, this research can be summarized as follows:

- Leaf betel ' temurose ' is betel leaf veins(nerves lateral) meet position section, so the shape symmetrical.

- In implementation riyadhoh make leaf betel ' temurose ' as the tasawuf media.

- Plant is something component importat in li fe humans, especially as source food and as medicine.Allah in theQur'an letter Thaha verse 53.

- Green betel leaves also have benefits as antibacterial because in them there are phenol and their derivatives, especially tannins, flavonoids, and saponins which are known as antibacterial. In addition, Betel is also commonly used to treat body odor and mouth, thrush, nosebleeds, itching, sores, and treat vaginal discharge in women. If a person's body is healthy and clean it will 
affect one's soul or soul. So that angels will dwell in one's soul. If angels are present in someone's soul, the angel will come whispering the joy and calm in the heart of the person .

- Betel leaves 'temurose' is betel leaf veins ( lateral nerves ) that meet the position of the segment, so that the shape is symmetrical (Ekosari \& Sugiarto, 2013). The green betel leaves that meet rose have a flavonoid content of 53,522 ppm, while the betel leaves which do not meet rose found flavonoid content of 43,041 ppm (Ekosari \& Sugiarto, 2013). It can be concluded that the content of the flavonoids of betel leaves rose higher than the betel leaves which did not meet rose.

\section{REFERENCES}

[1] S. Arikunto, "Research And Development", Bandung: Alfabeta, 2009.

[2] S. E. Aiello, "The Merck etinary manually", USA: Merck Sharp \& Dohme Corp, 2012.

[3] B. Ali, , et al, "Essential Oils Used In Aromatherapy: A Systemic Review", Asian Pac J Trop Biomed, 5 (8), pp. 60111, 2015.

[4] S. Amin, "Suing Sufism, Sufism and $21^{\text {st }}$ Century Social Responsibility", Cetakan II, Yogyakarta: Pustaka Pelajar, 2002.

[5] R. Anwar, "Sufism", Bandung: CV, Library Faithful, 2004.

[6] N. M. Armando, "Encyclopedia of Islam", Jakarta: PT Ichtiar Baru Van Hoeve, 2005.

[7] Ash-Syafrowi, Mahmud, "Inviting Angels to the House", Yogyakarta: Mutiara Media, 2013.

[8] N. Carolia, \& W. Noventi, "Potential of Betel Green Leaf Extract (Piper betle L.) as Alternative Therapy for Acne vulgaris", Majority, 5 (1), pp. 140-145, 2016.

[9] R. Ekosari, \& L. Sugiarto, "Physiological studies of 'temurose' betel leaf (The Physiaological study of 'temurose' betel leaves)", J. Basic Science, 2 (1), pp. 7-12, 2013.
[10] Fauzan, "Acculturation of Islam and Javanese Culture : Study on the "Ratification" Ritual of New Residents Faithful Brotherhood of the Heart of Terate", Journal of Religious Studies and Islamic Thought, 4 (1), pp. 105-124, 2012.

[11] M. Fauziah, "Family Medicinal Plants (TOGA)”, Depok: Penad Swadaya, 2007.

[12] R. Gavankar, et. al. "Phytochemistry Pharmacological Profile and Therapeutic Uses of Piper Betle Linn: An Overview", J Pharmacogn Phytochem, 1 (2), pp. 10-19, 2013.

[13] Hidayah, "Efficacy of Sourseed Leaves Spiritual (Online )", 2019. Accessed through http://ilmu-hikmah.com/khasiatdaun-sirih-sisi-spiritual/ on March 2, 2019.

[14] A. M. Ibrahim, "Test of Effectiveness of Green Betel Leaf Extract (Piper betle Linn) on the growth of streptococcus viridians bacteria with Disc diffusion method", Unpublishedthesis, Jakarta : Sta rtIslamic University Of Syarif Hidayatullah, 2013.

[15] S. Inayatullah, "Effects of Green Betel Leaf Extract (Piper Betle L.) on Staphylococcus Aureus Bacterial Growth", Jakarta : Hidayatullah Syarif State Islamic University, 2012.

[16] Kaskus, "Send Meet Rose A Myth (Online)", 2013. Accessed via https://www.kaskus.co.id/ on March 2, 2019.

[17] Kompasiana, "Kearifan Sirih dan Beragam manfaatnya (Online), 2006. Diakses melalui https://www.kompasiana.com/ tanggal 2 Maret 2019.

[18] Latifah, "Identification of Flavonoid Compounds and Antioxidant Activity Test on Kaempferia galanga Lime Rhizome Extract . With the DPPH Method (1,1Diphenyl-2-Pikrilhidrazil)", Maulana Malik Ibrahim Malang State Islamic University: Department of Chemistry, Faculty of Science and Technology, 2015.

[19] M.R. Patel, Y. T. Jasrai, "Evaluation of Fungitoxic Potency of Piper Betle L. (Mysore variety) Leafe Extracts Against Eleven Phyto Pathogenic Fungal 
Strains", Cibtech Journal of BioProtocols, 2 (2), pp. 21-28, 2013.

[20] Z. F. Putri, "Antibacterial activity test of the ethanol extract of betel leaf (Piper betle L.) against and multiresistant Staphylococcus Aureus (unpublished thesis)", Surakarta: Muhammadiyah University of Surakarta, 2010.

[21] N. Sayodih, "Education Research Method", Bandung: PT. Remaja Rosdakarya, 2009.

[22] M. Sidarta, "Kerifan Sirih and Various Benefits"( Online), 2016. Accessed via https://www.kompasiana.com/mawan.s idarta/ on March 2, 2019.

[23] A. Wei, \& T. Shibamoto, "Antioxidant and/Lipoxygenase Inhibitory Antioxidant Activities and Chemical Compositions of Selected Essential Oils", J Agriculture Food Chem, 58 (12), pp. 7218-25, 2010. 